\title{
Evidence of telomere attrition and a potential role for DNA damage in systemic sclerosis
}

\author{
Alicia Usategui ${ }^{1 \dagger}$, Cristina Municio ${ }^{1 \dagger}$, Elena G. Arias-Salgado², María Martín', Beatriz Fernández-Varas², \\ Manuel J. Del Rey ${ }^{1}$, Patricia Carreira ${ }^{1,3}$, Antonio González ${ }^{4}$, Gabriel Criado ${ }^{1}$, Rosario Perona ${ }^{2}$ and José L. Pablos ${ }^{1,3^{*}}$ (D)
}

\begin{abstract}
Background: To investigate the role of cell senescence in systemic sclerosis (SSc), we analyzed telomere shortening (TS) in SSc patients and the effect of targeting DNA damage in the bleomycin model of skin fibrosis.

Results: Telomere length (TL) in blood leukocytes of 174 SSc patients and 68 healthy controls was measured by Southern blot, and we found shorter age-standardized TL in SSc patients compared to healthy controls. TL was shorter in SSc patients with ILD compared to those without ILD and in anti-topoisomerase I positive compared to anti-centromere positive patients. To analyze the potential role of DNA damage in skin fibrosis, we evaluated the effects of the DNA protective GSE4 peptide in the bleomycin mouse model of scleroderma and the fibrotic response of cultured human dermal fibroblasts. Administration of GSE4-nanoparticles attenuated bleomycininduced skin fibrosis as measured by Masson's staining of collagen and reduced Acta2 and Ctgf mRNA expression, whereas transduction of dermal fibroblasts with a lentiviral GSE4 expression vector reduced COLIA1, ACTA2 and CTGF gene expression after stimulation with bleomycin or TGF- $\beta$, in parallel to a reduction of the phospho-histone H2A.X marker of DNA damage.

Conclusions: SSC is associated with TS, particularly in patients with lung disease or anti-topoisomerase I antibodies. Administration of GSE4 peptide attenuated experimental skin fibrosis and reduced fibroblast expression of profibrotic factors, supporting a role for oxidative DNA damage in scleroderma.
\end{abstract}

Keywords: Systemic sclerosis, Telomere length, Fibroblast

\section{Background}

The role of aging and cell senescence in fibrotic diseases is not clear since both pro- and anti-fibrotic cellular effects have been described. A consistent association between genetic or acquired telomere shortening (TS) and lung fibrosis has been identified in the last decades $[1,2]$. Mutations of telomerase and shelterin genes are

\footnotetext{
* Correspondence: jlpablos@h12o.es

${ }^{\dagger}$ Alicia Usategui and Cristina Municio contributed equally to this work. 'Servicio de Reumatología, Instituto de Investigación Hospital 12 de Octubre, 28041 Madrid, Spain

${ }^{3}$ Universidad Complutense de Madrid, Madrid, Spain

Full list of author information is available at the end of the article
}

associated with TS and represent the most common genetic factor associated with familial idiopathic pulmonary fibrosis and less frequently with sporadic forms of adult-onset pulmonary fibrosis [3, 4]. TS has been mechanistically linked to lung fibrosis through the reduced capacity of respiratory epithelial cells with TS to recover from damage, resulting in enhanced connective tissue repair and fibrosis [5, 6]. Cell-specific telomerase deficiency in type II alveolar epithelial cells impairs stem cell function and induces cell senescence, and it is sufficient to induce lung fibrosis [7]. Fibroblast senescence is also recognized as a potential pro-fibrotic mechanism

(c) The Author(s). 2022 Open Access This article is licensed under a Creative Commons Attribution 4.0 International License, which permits use, sharing, adaptation, distribution and reproduction in any medium or format, as long as you give appropriate credit to the original author(s) and the source, provide a link to the Creative Commons licence, and indicate if changes were made. The images or other third party material in this article are included in the article's Creative Commons licence, unless indicated otherwise in a credit line to the material. If material is not included in the article's Creative Commons licence and your intended use is not permitted by statutory regulation or exceeds the permitted use, you will need to obtain permission directly from the copyright holder. To view a copy of this licence, visit http://creativecommons.org/licenses/by/4.0/ The Creative Commons Public Domain Dedication waiver (http://creativecommons.org/publicdomain/zero/1.0/) applies to the data made available in this article, unless otherwise stated in a credit line to the data. 
but somewhat paradoxically, telomerase activity in lung fibroblasts may contribute to the development of experimental lung fibrosis, [8-10]. Fibroblast senescence is characterized by the secretion of profibrotic mediators and restrains myofibroblast dedifferentiation and apoptosis, favoring their accumulation [10, 11]. Fibroblasts from systemic sclerosis (SSc) skin show replicative senescence and decreased autophagic capacity, and targeting either oxidative stress or cell senescence may ameliorate fibrogenesis [12-14]. However, impaired profibrotic signaling and extracellular matrix production is also one of the hallmarks of aged fibroblasts [15-17].

In SSc, the prevalence and clinical significance of TS is controversial. Telomere shortening (TS) was first described in 1996 in a small cohort of SSc patients, including limited and diffuse cutaneous SSc (lcSSc and dcSSc), and intriguingly, also in their family members [18]. This observation led to the hypothesis that environmental exposure to DNA damaging agents was the triggering factor, but the finding was not reproduced in another lcSSc cohort [19]. Shortened TL has recently been reported in some SSc subsets, such as those with lung involvement or in a small group with autoantibodies against telomeric proteins [20-22]. Differences between these studies may relate to the different sample sizes, normal TL reference, or to the use of different leukocyte samples and techniques to determine TL $[23,24]$.

Southern blot of terminal restriction fragments (TRF) provides an absolute and highly reproducible measure of
TL [23]. We have taken advantage of this technique to determine TL in a large and prospectively characterized SSc cohort [25] and in healthy controls. We also examined the ability of the dyskerin derived GSE4 peptide, which protects DNA from oxidative damage and induces telomerase activity, to modify experimental skin fibrosis and to regulate profibrotic gene expression in cultured human fibroblasts [26-28].

\section{Results}

Telomere length in SSc patients and healthy controls

In both healthy controls (HC) and SSc groups, TL distribution showed a significant inverse correlation with age (Fig. 1A). A higher dispersion with a lower correlation coefficient were observed within the SSc group. SSc patients had a significantly decreased aged-adjusted z-score compared to $\mathrm{HC}(-0.84[-1.15,-0.62]$ vs $-0.00[-$ $0.28,0.31], p<0.0001$; Fig. 1B). Also, a higher proportion of patients with SSc showed a severely decreased TL, under the $\mathrm{z}$-score 10th percentile, (40.8\%) compared with $\mathrm{HC}(8.6 \%), p<0.0001$.

All clinical and serological SSc subsets had lower median TL compared to the HC group. The distribution of TL in the different SSc groups with different clinical and serological characteristics patients is shown in Table 1 and Fig. 1.

A lower TL was observed in the group of SSc patients with ILD compared to that without ILD $(-1.03[-1.63$, $-0.42]$ vs $-0.83[-1.62,0.32] ; \mathrm{p} 0.046)$. Also, patients

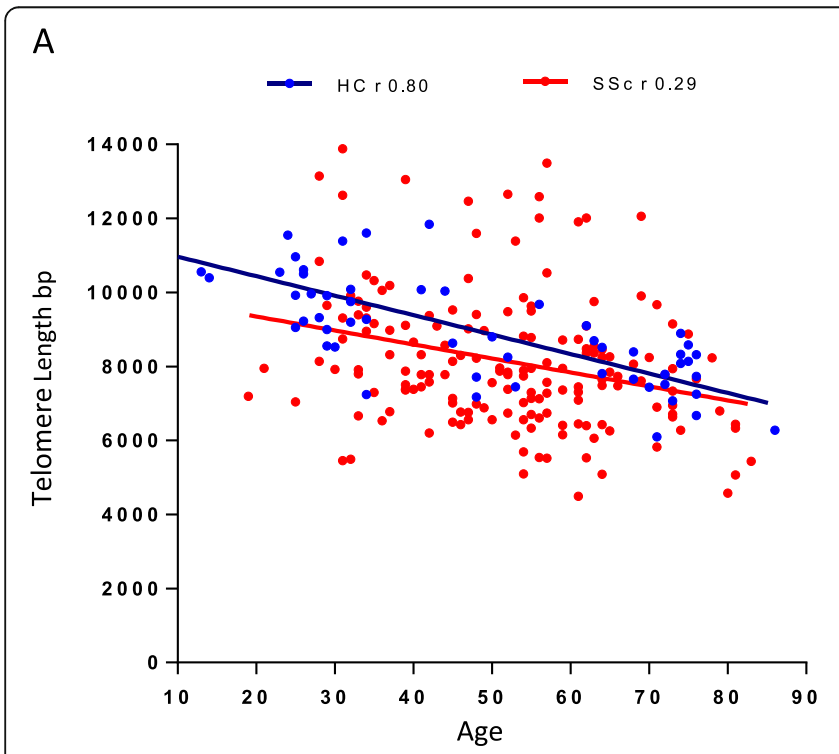

B

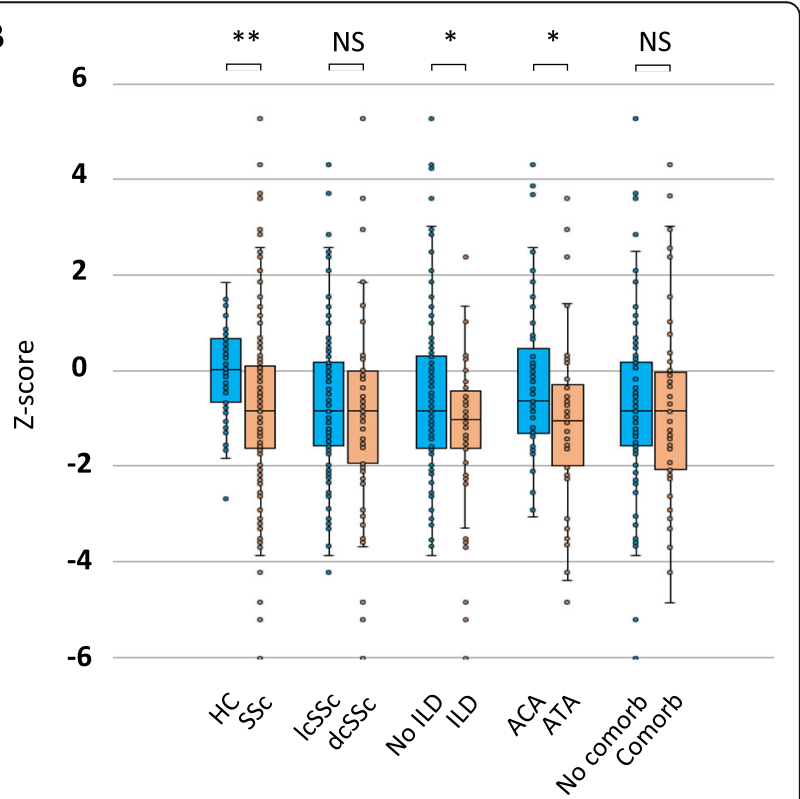

Fig. 1 Telomere length in SSc patients and healthy controls. A TL in bp as determined in whole blood DNA by TRF Southern blot in healthy controls (blue, $n$ 68) and SSc patients (red, n 174) plotted against age. $r$ indicates the TL/age correlation coefficient by Spearman rank test, SSc $p=0.0001$. HC $p<0.0001$. B TL z-score of healthy controls, SSc patients, and SSC clinical and serological subsets. Median and IQR [25,75\%] are represented. HC: healthy controls, IcSSc: limited cutaneous SSc, dcSSc: diffuse cutaneous SSc, ILD: Interstitial lung disease, ATA+: antitopoisomerase-I positive, ACA+: anti-centromere protein B positive, Comorb.: Comorbid conditions, NS: Non significant, ${ }^{*} p<0.05,{ }^{* *} p<0.0001$ 
Table 1 Age adjusted TL in SSc patients and controls

\begin{tabular}{|c|c|c|c|c|c|}
\hline & $\mathrm{N}$ & $\mathrm{TL}$ (z-score) ${ }^{1}$ & $\mathrm{p}$ & $<$ Percentile 10th n (\%) & $\mathrm{p}$ \\
\hline Healthy Controls & 68 & $-0.00[-0.28,0.31]$ & Ref & $6(9 \%)$ & Ref \\
\hline SSc patients & 174 & $-0.84[-1.15,-0.62]$ & $<0.0001$ & 71 (41\%) & $<0.0001$ \\
\hline deSSc & 69 & $-0.84[-1.93,0.05]$ & $<0.0001$ & $29(42 \%)$ & $<0.0001$ \\
\hline ICSSC & 105 & $-0.85[-1,57,0,18]$ & $<0.0001$ & 40 (38\%) & 0.0001 \\
\hline ILD & 57 & $-1.03[-1.63,-0.42]$ & $<0.0001$ & 24 (41\%) & $<0.0001$ \\
\hline No ILD & 117 & $-0.83[-1.62,0.32]$ & 0.004 & 45 (39\%) & 0.0001 \\
\hline ATA+ & 54 & $-1.04[-1.6,-0.03]$ & 0.0002 & $22(41 \%)$ & $<0.0001$ \\
\hline $\mathrm{ACA}+$ & 62 & $-0,63[-1.30,0.47]$ & 0.025 & $20(32 \%)$ & 0.0008 \\
\hline Comorbidity $^{2}$ & 115 & $-0.85[-1.58,0.18]$ & 0.0001 & $44(38 \%)$ & $<0.0001$ \\
\hline No comorbidity & 59 & $-0.84[-2.06,-0.02]$ & 0.0003 & $27(28 \%)$ & $<0.0001$ \\
\hline
\end{tabular}

${ }^{1}$ Median (IQR, 25-75\%). ${ }^{2}$ Comorbidity includes hypertension, hypercholesterolemia, diabetes, smoking or major adverse cardiovascular events (MACE). IcSSC: limited cutaneous SSc. dcSSc: diffuse cutaneous SSc. ILD: Interstitial lung disease. NS: Non significant. ATA+ (anti-topoisomerase-I positive), ACA+ (anti-centromeric protein B positive)

with anti-topoisomerase-I autoantibodies (ATA) showed a lower median TL compared to patients with anticentromere (anti-centromeric protein-B) autoantibodies (ACA) $(-1.04[-1.6,-0.03]$ vs $-0,63[-1.30,0.47]$; $\mathrm{p}$ $0.035)$. Since ILD is strongly associated to ATA, we analyzed TL in patients with ILD with or without ATA. TL was similarly decreased in patients with ILD, regardless their ATA status $(-1.04[-1.63,-0.54]$ vs $-0.83[-$ $1,53,-0,17], p=0.43)$.

We did not find differences in TL between lcSSc and $\mathrm{dcSSc}$ groups, nor by the presence or absence of previous comorbid conditions previously described associated with TS in the whole SSc group. Differences between SSc patients on different therapies, the presence of gastrointestinal, renal, cardiac involvement, or pulmonary arterial hypertension, were not detected (data not shown). No significant differences between the different SSc subsets regarding the proportion of severe TS (under percentile 10th) were observed. We did not find significant correlations between duration of the disease, extension of skin involvement measured as total skin score (TSS), nor lung fibrosis severity measured as forced vital capacity (FVC), and TL $\mathrm{z}$-scores (data not shown).

\section{Effects of the GSE4 peptide on experimental skin fibrosis and human fibroblasts}

GSE4 is a dyskerin related peptide that may induce telomerase activity and prevents telomere attrition induced by oxidative stress and DNA damage in different models of telomeropathies [26-28]. To analyze the potential effects of GSE4 on the development of skin fibrosis, we analyzed the effect of subcutaneous administration of GSE4-loaded nanoparticles in the bleomycin-induced model of scleroderma.

In bleomycin injected mice, dermal fibrosis and an increased collagen-stained area compared to control, saline-injected mice, were observed (Fig. 2A). The fibrotic area, evaluated as the fractional Masson's collagen-stained area of the dermis at 4 weeks, was significantly reduced in the group treated with GSE4nanoparticles compared to the scramble peptide nanoparticles control group (Fig. 2B). Gene expression of additional markers of fibrosis such as the myofibroblast marker $\alpha$-smooth muscle actin (Acta2) and the TGF- $\beta$ inducible connective tissue growth factor (Ctgf) was also consistently reduced in the skin of the GSE4 treated group (Fig. $2 \mathrm{C}$ and $\mathrm{D}$ ).

To examine the potential effects of GSE4 in human normal or SSc dermal fibroblasts, we treated cells with TGF- $\beta$ or bleomycin, two pro-fibrotic stimuli associated with the production of reactive oxygen species (ROS) and DNA damage in fibroblasts [29-31]. Although some differences were observed in the individual responses of different fibroblast lines, both SSc and control fibroblasts groups responded to TGF- $\beta$ or bleomycin by increasing the expression of profibrotic markers to a similar extent. Therefore, pooled data from SSc and normal fibroblasts on the effects of lentiviral expression of GSE4 and control peptides in fibroblasts are shown.

By quantitative RT-PCR analysis, we found an upregulation of CTGF, ACTA2 and COL1A1 gene expression in fibroblasts after TGF- $\beta$ or bleomycin treatment. In both cases, a significant reduction of both the basal and induced expression of these genes was observed in GSE4-transduced compared to control peptide transduced fibroblasts (Fig. 3A). These data indicate that expression of the GSE4 peptide is able to inhibit both basal and TGF- $\beta$ - or bleomycin-induced profibrotic gene expression in human dermal fibroblasts.

Bleomycin induced a significant increase in phospho-H2A.X, a robust marker of oxidative DNAdamage response [32], that was prevented by GSE4 but not scramble peptide expression in cultured dermal fibroblasts GSE4 (Fig. 3B). 


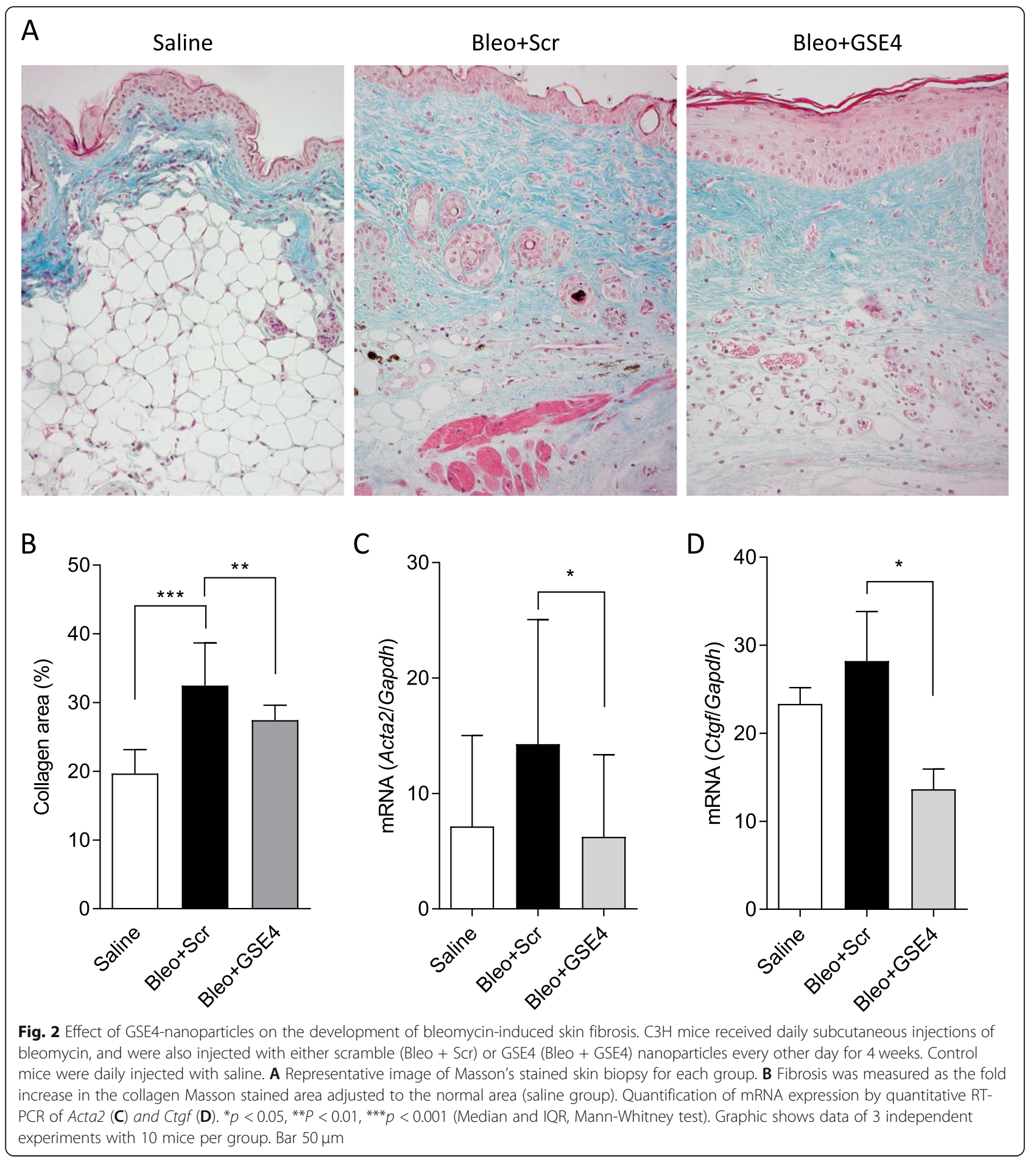

\section{Discussion}

Our data show a reduced age adjusted TL in SSc patients compared to controls. TS occurred in all disease subsets but it was more prominent in patients with lung involvement and in patients with anti-topoisomerase I antibodies, a serum marker also associated with lung involvement [33]. Previous studies have shown an association between TS and SSc lung disease but not in patients without lung disease $[20,21]$. Adler et al. recently reported shorter TL in SSc patients with autoantibodies against TERF1 telomeric protein, a feature that they found associated with severe lung disease [22]. The clinical associations of this autoantibody specificity and the meaning of TS in that subset of SSc patients requires 


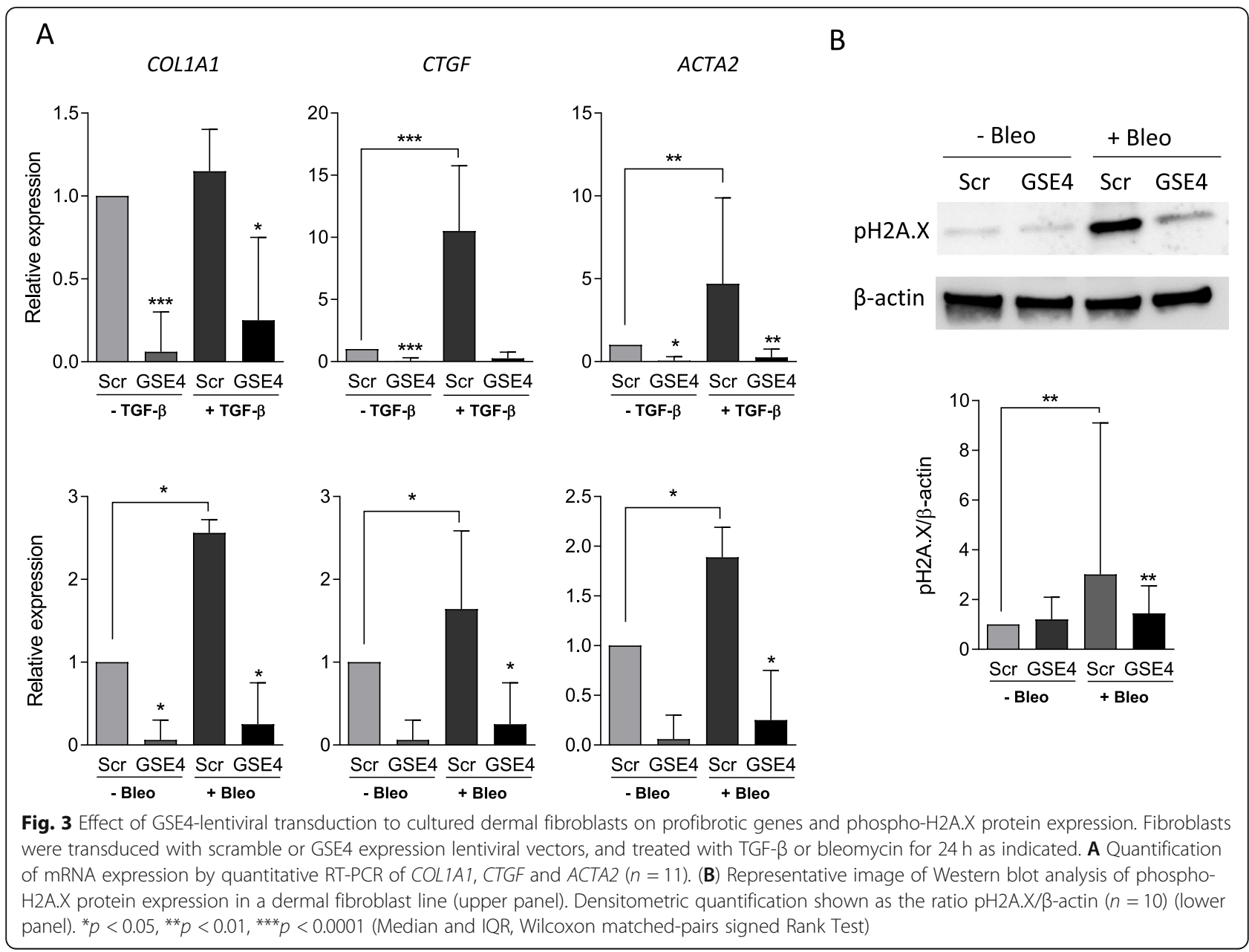

further confirmatory studies in different populations, since the prevalence of anti-telomeric autoantibodies seems low and highly variable in different ethnic groups.

We failed to detect correlations between TL and the duration or severity of skin or lung disease, suggesting that TS may be an early event and not a consequence of the progression of the disease. A similar observation has been reported in rheumatoid arthritis (RA), where TS was also independent of the duration and severity of the disease and associated with lung involvement [34]. In RA, TS was observed in both myeloid and lymphoid lineages, pointing to a hematopoietic stem cell defect [35].

In experimental lung fibrosis, TS and senescence of the epithelial cell component seem critical to the development of an abnormal reparative and fibrotic response, whereas the significance of TS in the stromal cell component is controversial $[8,10]$. However, in other organs where epithelial damage is not involved, such as scleroderma skin, the role of fibroblast senescence in the pathogenesis of fibrosis can be more relevant [14, 16, 36]. Telomerase activity is not detected in adult fibroblasts and TL is dependent on cell divisions and oxidative stress mediated DNA damage [36, 37]. Telomere shortening or dysfunction leads to fibroblast cell senescence in models of oxidative damage and fibrosis [9, 12, 38, 39]. Oxidative stress is one of the major drivers of aging and cell senescence by inducing DNA damage response and telomere shortening or dysfunction, and it is also a pivotal factor in the pathogenesis of SSc where it is involved in autoimmunity, vascular damage and fibrogenesis [40-42]. Therefore, we investigated the effects of the GSE4 peptide which has shown to antagonize this process in different disease models [26-28].

We show that treatment with GSE4-nanoparticles ameliorates skin fibrosis in the bleomycin model, similarly to what has been observed in bleomycin induced lung fibrosis [26]. In cultured skin fibroblasts, GSE4 reduced the expression of relevant profibrotic genes, particularly in response to bleomycin, an agent able to induce oxidative stress and DNA damage. GSE4 actions include multiple protective effects on DNA damage and telomere shortening or dysfunction, particularly under oxidative stress, in other cellular models. We failed to demonstrate telomerase activity in cultured fibroblasts 
treated with GSE4 (data not shown) but confirmed a reduction in the DNA damage response as shown by a reduction of phospho-H2A.X. Therefore, targeting different processes leading to cell senescence is a potential strategy to reduce fibrosis in SSc [17].

Interestingly, GSE4 also reduced profibrotic TGF- $\beta$ signaling in fibroblasts, an effect previously observed in alveolar epithelial cells [26]. Since TGF- $\beta$ is not expected to induce DNA-damage or telomere dysfunction the mechanism is unclear. TGF- $\beta$ signaling involves the production of mitochondrial ROS that promote Smad protein signaling, profibrotic gene expression and cell senescence $[29,30]$. Since all selected profibrotic genes are downstream TGF- $\beta$ signaling, it can be speculated that the observed effects of GSE4 on gene expression in unstimulated fibroblasts might relate to the signaling of autocrine TGF- $\beta$ by ROS. GSE4 has been shown to increase the expression levels of the antioxidant genes SOD1, SOD2 and catalase thus decreasing oxidative stress in two different cellular models of disease [27, 28].

\section{Conclusions}

Our results confirm an association between SSc and TS of peripheral blood leukocytes, and lower TL in the group of patients with lung involvement and ATA. Additionally, we have shown that targeting oxidative DNA damage with the dyskerin-derived GSE4 peptide reduces experimental skin fibrosis and profibrotic gene expression in human dermal fibroblasts. These findings suggest that processes leading to fibroblast senescence such as telomere attrition or DNA damage may be relevant pathogenic factors in the development of fibrosis in SSc and support the therapeutic potential of telomere or DNA protective strategies.

\section{Methods}

\section{Telomere length analysis}

TL was determined by Southern blot of DNA from 174 patients with SSc and 68 healthy age and sex-matched controls, from the same geographical area, and with a similar ethnic composition. Included SSc patients are part of a large prospectively characterized cohort with available whole blood DNA samples, representative of the unfractionated leukocyte pool. DNA from patients and controls had been collected along the same timeframe as part of previous genetic studies.

DNA was extracted by NZY gDNA isolation Kit (NZTech, Lisbon, Portugal) and its integrity checked by agarose gel electrophoresis. DNA was digested with 20 units/ $\mu \mathrm{l}$ of the Hinf I/Rsa I restriction enzymes at $37^{\circ} \mathrm{C}$ for $2 \mathrm{~h}$. Telomere length was determined using the TeloTAGGG Telomere Length Assay (Roche Diagnostics, Mannheim, Germany) using 1,5 $\mu \mathrm{g}$ of genomic DNA [23]. The TL in the healthy control group was used to establish a TL standard curve and to obtain a z-score measure of the deviation TL of individual SSc patients from the age standardized curve. The $\mathrm{z}$-score compared the TL value of each individual with the age-matched mean and standard deviation (SD) of the values obtained in the controls (individual's value - population mean/ population SD, age-matched population of within 9 years on average) [43]. Patient's characteristics at the time of TL determination are depicted in Table 2.

\section{Mouse model of skin fibrosis}

Dermal fibrosis was induced in 11 weeks old $\mathrm{C} 3 \mathrm{H} / \mathrm{HeNCrl}$ female mice (Charles River Laboratories; Saint Germain

Table 2 Demographic and clinical characteristics of SSc patients

\begin{tabular}{|c|c|}
\hline Variables & SSc population $(n=174)$ \\
\hline Age (median, IQR) & $54(21)$ \\
\hline Gender, female, n (\%) & $151(86.8)$ \\
\hline Race, Caucasian, n (\%) & $169(97.1)$ \\
\hline Smoking history, n (\%) & $74(42.5)$ \\
\hline \multicolumn{2}{|l|}{ Comorbidities, n (\%) } \\
\hline Diabetes mellitus & $15(8.6)$ \\
\hline Hypertension & $42(24.1)$ \\
\hline Dyslipidemia & $40(23.0)$ \\
\hline MACE & $11(6.3)$ \\
\hline Cancer & $14(8.1)$ \\
\hline Disease duration ${ }^{1}$ median $(\mathrm{IQR})$, years & $7(10)$ \\
\hline \multicolumn{2}{|l|}{ Disease subtype, n (\%) } \\
\hline ICSSC & $105(60.3)$ \\
\hline dcSSc & 69 (39.6) \\
\hline \multicolumn{2}{|l|}{ Autoantibodies, n (\%) } \\
\hline ATA & $54(31.0)$ \\
\hline ACA & $62(35.6)$ \\
\hline \multicolumn{2}{|l|}{ Clinical involvement of SSC, n (\%) } \\
\hline Pulmonary hypertension & $17(9.8)$ \\
\hline Pulmonary (ILD) & $57(32.7)$ \\
\hline Cardiac & $29(16.7)$ \\
\hline Gastrointestinal & $137(78.7)$ \\
\hline Renal & $7(4.0)$ \\
\hline \multicolumn{2}{|l|}{ Previous Therapy, n (\%) } \\
\hline Glucocorticoids & $98(56.3)$ \\
\hline Immunosuppressive drugs ${ }^{2}$ & $80(46.0)$ \\
\hline $\begin{array}{l}\text { Maximal mRSS ever, median } \\
\text { (IQR), range } 0-51\end{array}$ & $10(19)$ \\
\hline Death by any cause, $\mathrm{n}(\%)$ & $34(19.5)$ \\
\hline
\end{tabular}

${ }^{1}$ From first non-Raynaud disease manifestation. ${ }^{2}$ Azathioprine, Methotrexate, Cyclophosphamide, Mycophenolate mofetil, Rituximab or Leflunomide. (ILD) Interstitial lung disease. ICSSc limited cutaneous SSc, dcSSc diffuse cutaneous SSc, ATA anti-topoisomerase I antibodies, ACA anticentromere antibodies, $n$ number, mRSS modified Rodnan skin score. Clinical definitions are described in Additional file 1 and according to reference [25] 
Nuelles, France) by daily subcutaneous injection of $100 \mu \mathrm{g}$ of bleomycin $(1 \mathrm{mg} / \mathrm{ml}$; Mylan Pharmaceuticals, Barcelona, Spain) or $0.9 \%$ saline control into the shaved back skin for 4 weeks, as previously described [44].

To study the effect of GSE4 peptide in this model, 10 mice in each group were injected subcutaneously with $100 \mu \mathrm{l}(5 \mu \mathrm{g})$ of GSE4- or scramble-containing nanoparticles every other day in the same area of bleomycin injection. Nanoparticles were produced as previously reported $[45,46]$.

\section{Histology}

Skin was harvested and paraffin embedded for histological evaluation of the collagen dermal area by Masson's trichrome staining (Sigma-Aldrich, St. Louis, USA). Masson's stained full thickness skin sections were visualized on a Zeiss A1 microscope, and photographed and digitalized using an AxioCam ERc 5S camera and ZEN lite 2012 software (Zeiss, Jena, Germany). Collagen bluestained fractional area was quantified using ImageJ software (http://rsb.info.nih.gov/ij).

\section{Transduction of human dermal fibroblasts with lentiviral vectors for GSE4 expression}

Skin biopsies were obtained from involved forearm skin of 5 patients with SSc and 6 healthy individuals during minor skin surgery. Fibroblast cultures were established by explant growth in 10\% fetal bovine serum/Dulbecco's modified Eagle's medium (DMEM) (Lonza, Viviers, Belgium) and used between passages 4 and 9. Fibroblasts maintained in DMEM with $0.5 \%$ fetal bovine serum, were stimulated for $24 \mathrm{~h}$ with $1 \mu \mathrm{g} / \mathrm{ml}$ bleomycin or 1 $\mathrm{ng} / \mathrm{ml}$ of TGF- $\beta 1$ (Calbiochem, Darnstadt, Germany).

Lentiviral particles were produced in HEK $293 \mathrm{~T}$ cells by transfecting the scramble control (pRRL-CMVIRESEGFP) and GSE4-expressing (pRRL-CMV-GSE4-IRESEGFP) vectors together with pCD-NL-BH and pMD.2G VSV. G packaging plasmids as previously described [47]. Forty hours after transfection, supernatants were recovered and used to transduce dermal fibroblast cells. Efficiency of transduction was monitored by flow cytometry and quantitative RT-PCR.

\section{Real-time quantitative RT-PCR}

Total RNA from mouse skin biopsies and from human dermal fibroblasts was extracted using RNeasy Micro Kit (Qiagen, Copenhagen, Denmark) and TRI Reagent (Invitrogen) respectively, according to the manufacturer's protocol. For the quantification of mRNA, $1 \mu \mathrm{g}$ was used for first-strand complementary DNA synthesis with High Capacity cDNA Transcription Kit (Applied Biosystems, Foster City, CA, USA). Quantitative PCR (qPCR) analysis was carried out on a Roche LightCycler 480 II (Roche Diagnostics) instrument using Power Sybr Green
PCR Master Mix (Applied Biosystems) according to the manufacturer's recommendations. Primer sequences are listed in additional table (see Additional file 2). Gapdh (mouse) and HPRT (human) were used as endogenous reference. For relative quantification we compared the amount of target normalized to the endogenous reference using $2-\Delta \Delta \mathrm{Ct}$ formula ( $\mathrm{Ct}=$ threshold cycle).

\section{Phospho-histone H2A.X Western blot analysis}

Cell pellets were resuspended in lysis buffer $(50 \mathrm{mM}$ TRIS- $\mathrm{HCl} \mathrm{pH} 8.0,150 \mathrm{mM} \mathrm{NaCl}, 1 \% \mathrm{NP}-40,1 \% \mathrm{Na}-$ Deoxycolate, $0.1 \%$ SDS, $2 \mathrm{mM}$ EDTA pH 8.0) with a protease cocktail inhibitor (Roche Diagnostics). Protein concentration was determined by the DC method (BioRad Laboratories, Hercules, CA, USA). Cell lysates $(20 \mu \mathrm{g})$ were electrophoresed by SDS-PAGE and transferred to nitrocellulose membranes (Bio-Rad Laboratories). After blocking for $1 \mathrm{~h}$ with $10 \%$ BSA TBS-Tween, membranes were incubated overnight at $4{ }^{\circ} \mathrm{C}$ with antiphospho-histone H2A.X (1/1000; \#9718, Cell Signalling Massachusetts, USA). Secondary antibody was horseradish peroxidase-conjugated goat anti-rabbit IgG (1/2000; Invitrogen, G-21234, Carlsbad, CA, USA).

Values were normalized to $\beta$-actin levels detected by anti- $\beta$-actin HRP-conjugated antibody (1/25000; ab49900, Abcam). The protein bands were detected by chemiluminescence using ClarityTM Western ECL Substrate (Bio-Rad Laboratories, Hercules, CA, USA) in ImageQuantTM LAS 400 (GE Healthcare, Buckinghamshire, UK) and quantified by densitometry using ImageQuant TL (GE Healthcare).

\section{Statistical analyses}

Data were analyzed using GraphPad Prism software v6.0 (GraphPad Software, San Diego, CA, USA). Quantitative data were analyzed by Mann-Whitney test or Wilcoxon matched-pairs signed Rank Test as appropriate. Correlation between TL and numerical variables was determined by Spearman rank test. Chi-square test was used to compare the frequency of severe TS (z-score $<10$ th percentile) in SSc and controls or between the different SSc subsets. All quantitative data are described as medians with interquartile range.

\footnotetext{
Abbreviations

SSc: Systemic sclerosis; IcSSc: Limited cutaneous SSc; dcSSc: Diffuse cutaneous SSC; ILD: Idiopathic lung fibrosis; RA: Rheumatoid Arthritis; HC: Healthy Controls; MACE: Major adverse cardiovascular events; ATA: Anti-topoisomerase I antibodies; ACA: Anticentromere antibodies; n: Number; NS: Non significant; SD: Standard deviation; mRSS: Modified Rodnan skin score; TS: Telomere Shortening; TL: Telomere Length; COL1A1: Collagen type 1-alpha 1; ACTA2: a-smooth muscle actin; CTGF: Connective tissue growth factor; ROS: Reactive oxygen species; TSS: Total skin score; FVC: Forced vital capacity; DMEM: Dulbecco's modified Eagle's medium; qPCR: Quantitative PCR
} 


\section{Supplementary Information}

The online version contains supplementary material available at https://doi. org/10.1186/s12979-022-00263-2.

Additional file 1. Clinical definitions included in Table 2.

Additional file 2: Table S1. Primer sequences used for quantitative real-time PCR analysis.

\section{Acknowledgements}

We are grateful to Leandro Sastre for scientific advice and to Vanessa Miranda for technical assistance.

\section{Authors' contributions}

A.U., C. M, P. C, A. G, G. C, R. P and J.L.P. conceived and designed the experiments. A.U., C.M., E.G.A.G., M.M., B.F.V. and M.D.R. performed the research, collected and analyzed data. P.C. and A.G. provided samples. A.U. C.M., E.G.A.G., M.M., B.F.V, M.D.R., G.C., R.P. and J.L.P. interpreted data. A.U., C.M., G.C., R.P., J.L.P. wrote the paper. All authors read and approved the final manuscript.

\section{Funding}

The authors received financial support from Fondo de Investigación Sanitaria, Instituto de Salud Carlos III (PI19/01129, PI20/00335, and RIER network RD16/0012 RETICS program), co-financed by the European Regional Development Fund (FEDER).

\section{Availability of data and materials}

Data generated or analyzed during this study are included in this published article and its supplementary information files. Data not shown are available from the corresponding author on reasonable request.

\section{Declarations}

\section{Ethics approval and consent to participate}

All patients signed a written informed consent form. All human and animal procedures were approved by Clinical Research Committee and Animal Care and Use Committee of Hospital 12 de Octubre with protocol reference number PROEX 407/15 and carried out in accordance with the institutional guidelines.

\section{Consent for publication}

Not applicable.

\section{Competing interests}

The authors declare that they have no competing financial interests.

\section{Author details}

'Servicio de Reumatología, Instituto de Investigación Hospital 12 de Octubre, 28041 Madrid, Spain. ${ }^{2}$ Servicio de Telomeropatías, Instituto de Investigaciones Biomédicas CSIC/UAM; CIBER enfermedades raras; Instituto de Investigación Hospital Universitario La Paz, Madrid, Spain. ${ }^{3}$ Universidad Complutense de Madrid, Madrid, Spain. ${ }^{4}$ Experimental and Observational Rheumatology, Instituto de Investigacion Sanitaria, Hospital Clínico Universitario de Santiago, Santiago de Compostela, Spain.

Received: 21 October 2021 Accepted: 19 January 2022

Published online: 27 January 2022

\section{References}

1. Armanios MY, Chen JJ, Cogan JD, Alder JK, Ingersoll RG, Markin C, et al. Telomerase mutations in families with idiopathic pulmonary fibrosis. N Engl J Med. 2007:356(13):1317-26. https://doi.org/10.1056/NEJMoa066157.

2. Cronkhite JT, Xing C, Raghu G, Chin KM, Torres F, Rosenblatt RL, et al. Telomere shortening in familial and sporadic pulmonary fibrosis. Am J Respir Crit Care Med. 2008;178(7):729-37. https://doi.org/10.1164/rccm.2 00804-5500C.

3. Alder JK, Chen JJ-L, Lancaster L, Danoff S, Su S, Cogan JD, et al. Short telomeres are a risk factor for idiopathic pulmonary fibrosis. Proc Natl Acad Sci U S A. 2008;105(35):13051-6. https://doi.org/10.1073/pnas.0804280105.
4. Tsakiri KD, Cronkhite JT, Kuan PJ, Xing C, Raghu G, Weissler JC, et al. Adultonset pulmonary fibrosis caused by mutations in telomerase. Proc Natl Acad Sci U S A. 2007;104(18):7552-7. https://doi.org/10.1073/pnas.0701009104.

5. Chen R, Zhang K, Chen H, Zhao X, Wang J, Li L, et al. Telomerase deficiency causes alveolar stem cell senescence-associated low-grade inflammation in lungs. J Biol Chem. 2015;290(52):30813-29. https://doi.org/10.1074/jbc.M115. 681619

6. Alder JK, Barkauskas CE, Limjunyawong N, Stanley SE, Kembou F, Tuder RM, et al. Telomere dysfunction causes alveolar stem cell failure. Proc Natl Acad Sci U S A. 2015;112(16):5099-104. https://doi.org/10.1073/pnas.1504780112.

7. Liu T. Gonzalez De Los Santos F, Zhao Y, Wu Z, Rinke AE, Kim KK, et al. telomerase reverse transcriptase ameliorates lung fibrosis by protecting alveolar epithelial cells against senescence. J Biol Chem. 2019;294(22):886171. https://doi.org/10.1074/jbc.RA118.006615.

8. Pardo A, Selman M. Lung fibroblasts, aging, and idiopathic pulmonary fibrosis. Ann Am Thorac Soc. 2016;13(Suppl 5):S417-21. https://doi.org/10.1 513/AnnalsATS.201605-341AW.

9. Razdan N, Vasilopoulos T, Herbig U. Telomere dysfunction promotes transdifferentiation of human fibroblasts into myofibroblasts. Aging Cell. 2018;17(6):e12838. https://doi.org/10.1111/acel.12838.

10. Liu T, Chung MJ, Ullenbruch $M, Y u H$, Jin $H_{1}, H u$ B et al. Telomerase activity is required for bleomycin-induced pulmonary fibrosis in mice. J Clin Invest. 2007;117(12):3800-9. https://doi.org/10.1172/JCl32369.

11. Harada M, Hu B, Lu J, Wang J, Rinke AE, Wu Z, et al. The dual distinct role of telomerase in repression of senescence and myofibroblast differentiation. Aging (Albany NY). 2021;13(13):1695-73. https://doi.org/10.18632/aging.2 03246.

12. Kato K, Logsdon NJ, Shin YJ, Palumbo S, Knox A, Irish JD, et al. Impaired Myofibroblast dedifferentiation contributes to nonresolving fibrosis in aging. Am J Respir Cell Mol Biol. 2020;62(5):633-44. https://doi.org/10.1165/rcmb.2 019-00920C.

13. Schafer MJ, White TA, lijima K, Haak AJ, Ligresti G, Atkinson EJ, et al. Cellular senescence mediates fibrotic pulmonary disease. Nat Commun. 2017;8(1): 14532. https://doi.org/10.1038/ncomms14532.

14. Dumit VI, Küttner V, Käppler J, Piera-Velazquez S, Jimenez SA, BrucknerTuderman $\mathrm{L}$, et al. Altered MCM protein levels and autophagic flux in aged and systemic sclerosis dermal fibroblasts. J Invest Dermatol. 2014;134(9): 2321-30. https://doi.org/10.1038/jid.2014.69.

15. Quan T, Shao Y, He T, Voorhees JJ, Fisher GJ. Reduced expression of connective tissue growth factor (CTGF/CCN2) mediates collagen loss in chronologically aged human skin. J Invest Dermatol. 2010;130(2):415-24. https://doi.org/10.1038/jid.2009.224.

16. Martyanov V, Whitfield ML, Varga J. Senescence signature in skin biopsies from systemic sclerosis patients treated with Senolytic therapy: potential predictor of clinical response? Arthritis Rheumatol. 2019;71(10):1766-7. https://doi.org/10.1002/art.40934

17. Mancini OK, Acevedo M, Faze N, Cuillerier A, Ruiz AF, Huynh DN, et al. Oxidative stress-induced senescence mediates inflammatory and fibrotic phenotypes in fibroblasts from systemic sclerosis patients. Rheumatology (Oxford). 2021. https://doi.org/10.1093/rheumatology/keab477.

18. Artlett CM, Black CM, Briggs DC, Stevens CO, Welsh Kl. Telomere reduction in scleroderma patients: a possible cause for chromosomal instability. $\mathrm{Br}$ J Rheumatol. 1996;35(8):732-7. https://doi.org/10.1093/rheumatology/35.8.732.

19. Maclntyre A, Brouilette SW, Lamb K, Radhakrishnan K, McGlynn L, Chee MM, et al. Association of increased telomere lengths in limited scleroderma, with a lack of age-related telomere erosion. Ann Rheum Dis. 2008;67(12):1780-2. https://doi.org/10.1136/ard.2007.086652.

20. Lakota K, Hanumanthu VS, Agrawal R, Carns M, Armanios M, Varga J. Short lymphocyte, but not granulocyte, telomere length in a subset of patients with systemic sclerosis. Ann Rheum Dis. 2019;78(8):1142-4. https://doi.org/1 0.1136/annrheumdis-2018-214499.

21. Liu S, Chung MP, Ley B, French S, Elicker BM, Fiorentino DF, et al. Peripheral blood leucocyte telomere length is associated with progression of interstitial lung disease in systemic sclerosis. Thorax. 2021;76(12):1186-92. https://doi.org/10.1136/thoraxjnl-2020-215918.

22. Adler BL, Boin F, Wolters PJ, Bingham CO, Shah AA, Greider C, et al. Autoantibodies targeting telomere-associated proteins in systemic sclerosis. Ann Rheum Dis. 2021;80(7):912-9. https://doi.org/10.1136/annrheumdis-202 $0-218918$

23. Kimura M, Stone RC, Hunt SC, Skurnick J, Lu X, Cao X, et al. Measurement of telomere length by the southern blot analysis of terminal restriction 
fragment lengths. Nat Protoc. 2010;5(9):1596-607. https://doi.org/10.1038/ nprot.2010.124.

24. Alder JK, Hanumanthu VS, Strong MA, DeZern AE, Stanley SE, Takemoto CM, et al. Diagnostic utility of telomere length testing in a hospital-based setting. Proc Natl Acad Sci U S A. 2018;115(10):E2358-65. https://doi.org/10.1 073/pnas. 1720427115.

25. Joven BE, Escribano P, Andreu JL, Loza E, Jimenez C, de Yebenes MJG, et al. 2013 ACR/EULAR systemic sclerosis classification criteria in patients with associated pulmonary arterial hypertension. Semin Arthritis Rheum. 2018; 47(6):870-6. https://doi.org/10.1016/j.semarthrit.2017.10.006.

26. Pintado-Berninches L, Montes-Worboys A, Manguan-García C, Arias-Salgado EG, Serrano A, Fernandez-Varas B, et al. GSE4-loaded nanoparticles a potential therapy for lung fibrosis that enhances pneumocyte growth, reduces apoptosis and DNA damage. FASEB J. 2021;35(3):e21422. https:// doi.org/10.1096/fj.202001160RR.

27. larriccio L, Manguán-García C, Pintado-Berninches L, Mancheño JM, Molina A, Perona R, et al. GSE4, a Small Dyskerin- and GSE24.2-Related Peptide, Induces Telomerase Activity, Cell Proliferation and Reduces DNA Damage, Oxidative Stress and Cell Senescence in Dyskerin Mutant Cells. PLoS One. 2015;10(11):e0142980.

28. Pintado-Berninches L, Fernandez-Varas B, Benitez-Buelga C, Manguan-Garcia C, Serrano-Benitez A, larriccio L, et al. GSE4 peptide suppresses oxidative and telomere deficiencies in ataxia telangiectasia patient cells. Cell Death Differ. 2019;26(10):1998-2014. https://doi.org/10.1038/s41418-018-0272-7.

29. Jain M, Rivera S, Monclus EA, Synenki L, Zirk A, Eisenbart J, et al. Mitochondrial reactive oxygen species regulate transforming growth factor$\beta$ signaling. J Biol Chem. 2013;288(2):770-7. https://doi.org/10.1074/jbc. M112.431973.

30. Liu RM, Desai LP. Reciprocal regulation of TGF- $\beta$ and reactive oxygen species: a perverse cycle for fibrosis. Redox Biol. 2015;6:565-77. https://doi. org/10.1016/j.redox.2015.09.009.

31. Rubio MA, Davalos AR, Campisi J. Telomere length mediates the effects of telomerase on the cellular response to genotoxic stress. Exp Cell Res. 2004; 298(1):17-27. https://doi.org/10.1016/j.yexcr.2004.04.004.

32. von Zglinicki T, Saretzki G, Ladhoff J. d'Adda di Fagagna F, Jackson SP. Human cell senescence as a DNA damage response. Mech Ageing Dev. 2005;126(1):111-7. https://doi.org/10.1016/j.mad.2004.09.034.

33. Jaeger VK, Wirz EG, Allanore Y, Rossbach P, Riemekasten G, Hachulla E, et al. Incidences and risk factors of organ manifestations in the early course of systemic sclerosis: a longitudinal EUSTAR study. PLoS One. 2016;11(10): e0163894. https://doi.org/10.1371/journal.pone.0163894.

34. Steer SE, Williams FM, Kato B, Gardner JP, Norman PJ, Hall MA, et al. Reduced telomere length in rheumatoid arthritis is independent of disease activity and duration. Ann Rheum Dis. 2007;66(4):476-80. https://doi.org/1 0.1136/ard.2006.059188.

35. Schönland SO, Lopez C, Widmann T, Zimmer J, Bryl E, Goronzy JJ, et al. Premature telomeric loss in rheumatoid arthritis is genetically determined and involves both myeloid and lymphoid cell lineages. Proc Natl Acad Sci U S A. 2003;100(23):13471-6. https://doi.org/10.1073/pnas.2233561100.

36. Prowse KR, Greider CW. Developmental and tissue-specific regulation of mouse telomerase and telomere length. Proc Natl Acad Sci U S A. 1995; 92(11):4818-22. https://doi.org/10.1073/pnas.92.11.4818.

37. Richter T, von Zglinicki T. A continuous correlation between oxidative stress and telomere shortening in fibroblasts. Exp Gerontol. 2007;42(11):1039-42. https://doi.org/10.1016/j.exger.2007.08.005.

38. Lagnado A, Leslie J, Ruchaud-Sparagano MH, Victorelli S, Hirsova P, Ogrodnik M, et al. Neutrophils induce paracrine telomere dysfunction and senescence in ROS-dependent manner. EMBO J. 2021;40(9):e106048. https:// doi.org/10.15252/embj.2020106048.

39. Nozaki Y, Liu T, Hatano K, Gharaee-Kermani M, Phan SH. Induction of telomerase activity in fibroblasts from bleomycin-injured lungs. Am J Respir Cell Mol Biol. 2000;23(4):460-5. https://doi.org/10.1165/ajrcmb.23.4.3958.

40. López-Otín C, Blasco MA, Partridge L, Serrano M, Kroemer G. The hallmarks of aging. Cell. 2013;153(6):1194-217. https://doi.org/10.1016/j. cell.2013.05.039.

41. Casciola-Rosen L, Wigley F, Rosen A. Scleroderma autoantigens are uniquely fragmented by metal-catalyzed oxidation reactions: implications for pathogenesis. J Exp Med. 1997;185(1):71-9. https://doi.org/10.1084/jem.1 85.1.71.

42. Doridot L, Jeljeli M, Chêne C, Batteux F. Implication of oxidative stress in the pathogenesis of systemic sclerosis via inflammation, autoimmunity and fibrosis. Redox Biol. 2019;25:101122. https://doi.org/10.1016/j.redox.2019.1 01122.

43. Planas-Cerezales L, Arias-Salgado EG, Buendia-Roldán I, Montes-Worboys A, López CE, Vicens-Zygmunt V, et al. Predictive factors and prognostic effect of telomere shortening in pulmonary fibrosis. Respirology. 2019;24(2):14653. https://doi.org/10.1111/resp.13423.

44. Santiago B, Gutierrez-Cañas I, Dotor J, Palao G, Lasarte JJ, Ruiz J, et al. Topical application of a peptide inhibitor of transforming growth factorbeta1 ameliorates bleomycin-induced skin fibrosis. J Invest Dermatol. 2005; 125(3):450-5. https://doi.org/10.1111/j.0022-202X.2005.23859.x.

45. Egusquiaguirre SP, Manguan-Garcia C, Pintado-Berninches L, larriccio L, Carbajo D, Albericio F, et al. Development of surface modified biodegradable polymeric nanoparticles to deliver GSE24.2 peptide to cells: a promising approach for the treatment of defective telomerase disorders. Eur J Pharm Biopharm. 2015;91:91-102.

46. Egusquiaguirre SP, Manguan-Garcia C, Perona R, Pedraz JL, Hernandez RM, Igartua M. Development and validation of a rapid HPLC method for the quantification of GSE4 peptide in biodegradable PEI-PLGA nanoparticles. J Chromatogr B Analyt Technol Biomed Life Sci. 2014;972:95-101. https://doi. org/10.1016/j.jchromb.2014.09.041.

47. Salmon P, Trono D. Production and titration of lentiviral vectors. Curr Protoc Hum Genet. 2007:Chapter 12:Unit 12.10

\section{Publisher's Note}

Springer Nature remains neutral with regard to jurisdictional claims in published maps and institutional affiliations.
Ready to submit your research? Choose BMC and benefit from:

- fast, convenient online submission

- thorough peer review by experienced researchers in your field

- rapid publication on acceptance

- support for research data, including large and complex data types

- gold Open Access which fosters wider collaboration and increased citations

- maximum visibility for your research: over $100 \mathrm{M}$ website views per year

At BMC, research is always in progress.

Learn more biomedcentral.com/submissions 